\title{
Hubungan Antara Materi \\ Muatan Penjelasan dan Materi Muatan Batang Tubuh UuD 1945 \\ Studi Tentang Sistem Pemerintahan Negara
}

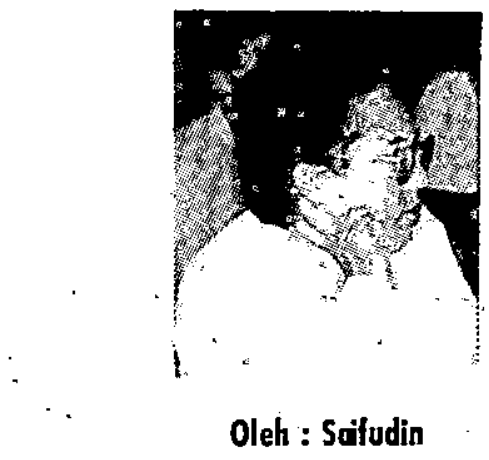

Meskipun terdapat sedikit perbedaan antara sistem pemerintahan dalam Penjelasan dengan sistem pemerintahan dalam Batang Tubuh Undang-undang Dasar 1945, namun menurut Saifudin, adanya pertanggungjawaban Presiden

kepada MPR dalăm Penjelasan lebih memberikan arti positif dalam rangka responsible goverment dalam sistem pemerintahan di Indonesia. Oleh karena itu, meskipun secara teoritis Penjelasan tidak boleh bertentangan dengan 'Batang Tubuh-nya, namun dalam masalah sistem pemerintahan dalam Penjelasan UUD 1945 ini tidak perlu dilakukan perubahan.

\section{Pendahuluan}

Rancangan Undang-undang Dasar yang disahkan oleh Badan Penyelidik Usahausaha Persiapan Kemerdekaan Indonesia (BPUPK!) tanggal 16 Juli 1945, tidak membuat atau memutuskan untuk membuat suatu memori penjelasan resmi undangundang dasar. ${ }^{1}$ Hasil kerja panitia Perancang Undang-undang Dasar dari BPUPKI ini selanjutnya dipakai oleh Panitia Persiapan
Kemerdekaan Indonesia (PPKI) dalam menyusun dan merumuskan Undang-undang Dasar. Sehari setelah Proklamasi Kemerdekaan Republik Indonesia (RI). tepatnya tanggal 18 Agustus 1945 PPKI berhasil menetapkan dan mengesahkan Undang-undang Dasar Negara kesatuan Ri yang dikemudian hari terkenal dengan sebutkan Undang-undang Dasar 1945.

Undang-undang Dasar 1945 yang telah

1 Bagir Manan, "Hubungan Antara Pusat dan Daerah Menurut UUD 1945", Disertasi , Unpad, Bandung, 1990. halaman 333. 
disahkan dan ditetapkan oleh PPKI menjadi landasan konstitusional dalam negara Rl ini, hanya meliputi Pembukaan dan Batang Tubuh Undang-undang Dasar 1945 yang memuat 16 Bab terdiri atas 37 Pasal, 4 Pasal Aturan Peralihan dan 2 ayat Aturan Tambahan. ${ }^{2}$ Naskah lengkap dari Undangundang Dasar ini selanjutnya dimuat secara resmi oleh pemerintah dalam Berita Republik Indonesia (BRI) Nomor 7 Tahun If tanggal 15 Februari 1946 halaman 45 s/d 48. Mengenai Penjelasan Undang-undang Dasar 1945 baik penjelasan umum maupun penjelasan pasal demi pasal tidak ikut dirundingkan/dimusyawarahkan dalam sidang PPKI tanggal 18 Agustus 1945, apalagi ditetapkan menjadi bagian dari Undang-undang Dasar 1945. ${ }^{3}$ Jadi berkaitan dengan penjelasan Undang-undang Dasar 1945, baik BPUPKI yang merencanakan undang-undang dasar maupun PPKI yang mengesahkan dan menetapkan undangundang dasar tidak pernah membuat atau memutuskan membuat memori penjelasan sebagai penjelasan resmi atau penjelasan othentik Undang-undang Dasar. ${ }^{4}$

Akan tetapi naskah Penjelasan Undangundang Dasar 1945 ternyata dimuat juga dalam BRI nomor, tahun dan tanggal yang sama dengan Pembukaan dan Batang Tubuh Undang-undang Dasar 1945, namun telah diselingi dengan pemuatan naskah-naskah lain. ${ }^{5}$ Artinya naskah Pembukaan dan Batang Tubuh Undang-undang Dasar 1945 dimuat pada halaman $45 \mathrm{~s} / \mathrm{d} 48$, sedangkan Penjelasan Undang-undang Dasar 1945 dimuat pada halaman $51 \mathrm{~s} / \mathrm{d} 56 \mathrm{BRI}$ nomor 7 Tahun II tanggal 15 Februari 1946.
Selanjutnya melalui Surat Keputusan Presiden No. 150 tentang Dekrit Presiden 5 Juli 1959 yang memberlakukan kembali Undang-undang Dasar 1945 yang "lampirannya" dimuat dalam Lembaran Negara No. 75 Tahun 1959, Penjelasan dimuat kembali bersama-sama dengan Pembukaan dan Batang Tubuh Undangundang Dasar 1945.

Adanya kenyataan tersebut, maka bertalian dengan Penjelasan Undang-undang Dasar 1945 dapat dimunculkan berbagai pertanyaan seperti dari mana asalnya Penjelasan, siapa yang membuat Penjelasan, mengapa ada Penjelasan dan bagaimana hubungan materi muatan Penjelasan dengan materi muatan Batang Tubuh Undang-undang Dasar 1945 ?

Oleh karena luasnya materi muatan Penjelasan, maka tulisan ini membatasi pada ruang lingkup "Studi Tentang Sistem Pemerintahan Negara". Dipilihnya masalah ini, mengingat adanya sistem pemerintahan pada dasarnya adalah merupakan upaya pembatasan kekuasaan antara eksekutif dan legislatif.

\section{Penyusunan dan Penetapan Undang-undang Dasar 1945}

Memasuki tahun 1945 tentara Jepang dalam peperangan di Asia Tenggara, mengalami kekalahan-kekalahan dan semakin terdesak oleh Negara-negara Sekutu. Menyadari kondisinya yang tidak menguntungkan, Pemerintah Jepang mulai memperhatikan nasib barigsa Indonesia. Berbagai langkah politik ditempuh oleh Pemerintah Jepang untuk menarik simpati

2. Muhammad Yamin, "Naskah Persiapan UUD 1945", Jilid Pertama, 1971, halaman 399 s/d 437.

3. J.C.T. Simorangkir, "Penetapan UUD Dilihat Dari Segi limu Hukum Tata Negara", Cetakan -, Gunung Agung, Jakarta, 1984, halaman 22. Lihat juga Jeoniarto Dalam "Sejarah Ketatanegaraan RI", Bina Aksara, Jakarta, 1986, halaman 18 s/d 19.

4. Bagir Manan, loc. cit.

5. Naskah lain tersebut adalah "Pembentukan Daerah dan Kementerian Negara" (halaman 48 s/d 49). "Maklumat Pemerintah dan Maklumat Politik" (halaman $49 \mathrm{~s} / d$ 51). Lihat J. C. T. Simorangkir, op. cit., halaman 29. 
dan dukungan bangsa Indonesia dalam melawan tentara Sekutu. Perwujudan kongkrit terhadap janji-janji politik Pemerintah Jepang, adalah dibentuknya BPUPKI pada tanggal 1 Maret $1945 .^{6}$ BPUPKI ini diketuai oleh' Dr. Radjiman Wediodiningrat dengan dibantu oleh dua orang wakil ketua yakni RP Soeroso dan Ichibangase.

Bertalian dengan pembentukan BPUPKI ini beberapa hal yang menarik untuk dikaji adalah sebagai berikut:

\section{Keanggotaan BPUPKI}

BPUPKI ini jumlah anggotanya sebanyak 62 orang termasuk ketua dan dua orang wakil ketuanya. ${ }^{7}$ Pada permulan persidangan periode kedua, Ketua BPUPKI telah melakukan penambahan jumlah anggota sebanyak enam orang. ${ }^{8}$ Dari keseluruhan anggota BPUPKI tampak bahwa badan ini belum sepenuhnya merupakan perwakilan bangsa Indonesia secara keseluruhan. Sebab, meskipun terdapat anggota-anggota yang berasal dari luar Jawa, tetapi anggota-anggota BPUPKI hanya pemimpin-pemimpin Indonesia yang berada di Pulau Jawa. ${ }^{9}$ Dilihat dari segi asal kelahirannya, perwakilan terbanyak dari Jawa Tengah.yang hampir mencapai 26 orang
$(41,93 \%)$ dari total keseluruhan anggota BPUPKI. Urutan berikutnya adalah perwakilan dari Jawa Timur sebanyak 14 orang $(22,58 \%)$, dan disusul oleh Jawa Barat 11 orang $(15 \%)$. Selebihnya berasal dari luar Jawa. Akan tetapi ada daerah-daerah seperti Bali dan Nusa Tenggara yang belum terdapat perwakilannya. ${ }^{10}$ Meskipun dari aspek keterwakilan wilayah, keanggotaan BPUPKI belum sepenuhnya mewakili bangsa Indonesia, namun dari aspek keterwakilan "golongan" tampaknya BPUPKI cukup representatif. Sebab, di dalam BPUPKI terdapat perwakilan dari golongan nasionalis, Islam, Katholik, Arab dan Tionghoa.

\section{Tugas dan Kegiatan BPUPKI}

Pendirian BPUPKI oleh Pemerintah Jepang, pada mulanya dimaksudkan hanya untuk melakukan penyelidikan bagi usahausaha persiapan kemerdekaan Indonesia. Jadi suatu tugas yang masih abstrak dalam menuju ke arah Indonesia merdeka. Akan tetapi BPUPKI dalam waktu yang relatif singkat telah mengadakan 2 kali persidangan. Dalam persidangan periode pertama $29 \mathrm{Mei}$ s/d 1 Juni 1945, BPUPKI telah membicarakan "dasar negara" yang kemudian pada tanggal 22 Juni 1945 dituangkan dalam Rancangan

6. Sri Soemantri M, "Prosedur dan Sistem Perubahan Konstitusi", Cetakan IV, Alumni Bandung, 1987, halaman 24 dalam catatan kaki nomor 20. Lihat juga George Mc Tuman Kahin, "Nasionalisme dan Revolusi di Indonesia", tejemahan Ismail bin Muhammad dan Zaharom bin Abdul Rashid, Cetakan Pertama, Dewan Bahasa dan Pustaka Kementrian Pelajaran Malaysia, Kuala Lumpur, 1980, halaman 151. Sementara itu A.G. Pringgodigdo mengemukakan bahwa pembentukan BPUPKI adalah tanggal 29 April 1945. Lihat A.G. Pringgodigdo. "Perubahan Kabinet Presidensiil Menjadi Kabinet Partementer", Yayasan Fons UGM, Yogyakarta, tanpa tahun. halaman 12.

7. Jumlah anggota BPUPKI ini sebenamya 63 orang, sebab dalam penyebutan nomor urut 62 temyata digunakan untuk dua orang yakni RP Soeroso dan lchibangase. Apabila Ichibangase yang merupakan satu-satunya orang Jepang tidak dihitung, maka betul bahwa jumlah anggota BPUPKI 62 orang. Lihat Moh. Tolchah Mansoer, "Pembahasan Beberapa Aspek Kekuasaan-kekuasaan Eksekutif dan Legislatif di Indonesia", Disertasi, Cetakan Kedua, Pradnya Paramita, Jakarta, 1977, halaman 2.

8. Mohammad Yamin, op. cit., halaman 45.

9. Mohammad Hatta, "Sekitar Proklamasi", Cetakan Kedua, Tintamas, Jakarta, 1970, halaman 19. Lihat juga George Mc Turnan Kahin, op. cit., halaman 151.

10. Diolah dari biodata anggota BPUPKI dan PPKI terbitan Sekretariat Negara. Lihat Saafaroedin Bahar, "Risalah Sidang BPUPKI dan PPKI", Cetakan Kedua, Edisi II, Sekretariat Negara, Jakarta, 1992, halaman lampiran bagian $B$. 
Pembukaan Undang-undang Dasar dan dikenal dengan "Piagam Jakarta". Sedangkan pada persidangan periode kedua tanggal 10 Juli s/d 16 Juli 1945, BPUPKI telah berhasil menyusun Rancangan Undangundang Dasar.

Dari hasil kerja BPUPKI dalam sidang pertama maupun kedua tersebut, memperlihatkan bahwa badan ini secara sadar telah menempatkan diri sebagai suatu "Lembaga Konstituante". Sebab, suatu Rancangan Undang-undang Dasar biasanya merupakan wewenang badan khusus yang ditugasi untuk suatu perubahan atau penggantian undang-undang dasar.

Setelah BPUPKI menyelesaikan tugastugasnya, badan ini pada tanggal 7 Agustus 1945 dibubarkan oleh Pemerintah Jepang. Selanjutnya Pemerintah Jepang membentuk PPKI yakni suatu panitia yang diserahi tugas untuk melakukan persiapan ke arah kemerdekaan Indonsia. Akan tetapi, sebelum Pemerintah Jepang memberikan kemerdekaan kepada Indonesia, Jepang telah menyerah tanpa syarat kepada Sekutu. Oleh karena itu, kesempatan tersebut dimanfaatkan sebaik-baiknya oleh bangsa Indonesia. Pada tanggal 17 Agustus 1945 Soekarno dan Mohammad Hatta atas nama bangsa Indonesia memproklamirkan lahirnya Negara Republik Indonesia.

Untuk melengkapi kelahiran negara Indonesia tersebut, PPKI setelah dilakukan penambahan anggota oleh Soekarno, mengadakan sidang pada tanggal 18 Agustus 1945, Hasil persidangan PPKI ini antara lain menetapkan dan mengesahkan Pembukaan dan Rancangan Undang- undang Dasar hasil karya BPUPKI sebagai Undang-undang Dasar Negara Republik Indonesia yang sekarang terkenal dengan sebutan Undang-undang Dasar 1945. Satu hal yang penting diketahui adalah bahwa PPKI hanya menetapkan Pembukaan dan Batang.Tubuh Undang-undang Dasar 1945. Penjelasan Undang-undang Dasar 1945 tidak ikut ditetapkan sebagai bagian dari Undangundang Dasar 1945 seperti yang dapat dilihat sekarang ini.

\section{Penjelasan Undang-undang Dasar 1945.}

Undang-undang Dasar 1945 yang terdiri atas 3 bagian yakni Pembukaan, Batang Tubuh dan Penjelasan merupakan undangundang dasar yang unik. Keunikan Undangundang Dasar 1945 ini terletak pada adanya "Penjelasan", karena tidak lazim undangundang dasar mempunyai Penjelasan. Hanya terdapat dua konstitusi yang mempunyai Penjelesan yakni Undangundang Dasar 1945 dan Konstitusi Philipina 1973. ${ }^{11}$

Adanya Penjelasan Undang-undang Dasar 1945 tidak dapat dipisahkan dari materi muatan yang dituangkan dalam Batang Tubuhnya yang memuat $16 \mathrm{Bab}, 37$ Pasal, 4 Pasal Aturan Peralihan dan 2 ayat Aturan Tambahan. Apabila dibandingkan dengan undang-undang dasar negara lain, maka Undang-undang Dasar 1945 ini merupakan undang-undang dasar yang tersingkat nomor satu di dunia. ${ }^{12}$ Apakah Undang-undang Dasar 1945 yang tersingkat nomor satu di dunia ini telah mengatur materi muatan yang diatur dalam suatu konstitusi ? Bertalian

11. Lihat Sri Soemantri, "Sistem-sistem Pemerintahan Negara-negara ASEAN", Tarsito, Bandung, 1976, halaman 195 s/d 273. Bandingkan dengan Sri Soemantri dalam "Tentang Lembaga-lembaga Menurut UUD 1945", Cetakan Kelima, Alumni Bandung, 1986, halaman 120.

12. Si Soemantri M,"Prosedur ...", op. cit., halaman 4. Akan tetapi Wirjono Prodjodikoro mengemukakan bahwa konstitusi terpendek adalah dari Spanyol yaitu 36 pasal, sedangkan konstitusi terpanjang adalah India 394 pasal. Untuk negara-negara lain jumlah pasal dari konstitusinya berkisar antara 100 dan 200 . Lihat Wirjono Prodjodikoro, "Asas-asas Hukum Tata Negara di Indonesia", Cetakan kelima, Dian Rakyat, Jakarta, 1983, halaman 11. 
dengan hal tersebut, Sri Soemantri mengemukakan adanya tiga pokok materi muatan dalam suatu konstitusi sebagai berikut:

Pertama : adanya jaminan terhadap hakhak asasi manusia dan warga negara;

Kedua : ditetapkannya susunan ketatanegaraan suatu negara yang bersifat fundamental; dan

Ketiga : adanya pembagian dan pembatasan tugas ketatanegaraan yang bersifat fundamenta! ${ }^{13}$

Apabila dilihat dari tiga materi muatan tersebut, maka ternyata Undang-undang Dasar 1945 telah memuat tiga pokok materi muatan yang harus diatur dalam konstitusi. ${ }^{14}$

Pada dasarnya jumlah pasal yang dimuat dalam suatu Undang-undang dasar bukan merupakan masalah yang prinsipil. Artinya nilai dari suatu konstitusi tidak diukur dari jumlah pasal yang dimuat di dalamnya $\mathrm{KC}$. Wheare menegaskan bahwa yang seharusnya terkandung di dalam suatu konstitusi adalah "the very minimum, and that minimum to be rules of law" (hal-hal yang teramat minimum, dan yang minimum itu merupakan aturan hukum). ${ }^{15}$ Atas dasar pendapat K.C. Wheare tersebut, maka sebenarnya Undang-undang Dasar 1945 termasuk dalam kualifikasi undang-undang dasar yang baik karena hanya memuat 37 pasal, 4 pasal Aturan Peralihan dan 2 ayat Aturan Tambahan serta telah mencakup tiga pokok materi muatan suatu konstitusi.
Meskipun demikian untuk memudahkan dalam memahami isi dan makna Undangundang Dasar 1945, undang-undang dasar ini dilengkapi dengan "Penjelasan Undangundang Dasar 1945." Dalam praktek ketatanegaraan keberadaan dan peranan Penjelasan Undang-undang Dasar 1945 tidak dapat dipungkiri telah memberikan sumbangan yang besar dalam memahami materi muatan yang dituangkan dalam Pembukaan dan Batang Tubuh Undangundang Dasar 1945. Oleh karena itu, yang perlu dikemukakan lebih lanjut adalah sebagai berikut:

\section{Asal-usul adanya Penjelasan Undang- undang Dasar 1945}

Sebagaimana yang telah dikemukakan terdahulu, PPKI dalam sidang 18 Agustus 1945 hanya menetapkan Pembukaan dan Batang Tubuh, tanpa Penjelasan Undangundang Dasar 1945. Masalahnya adalah dari mana asalnya Penjelasan Undang-undang Dasar 1945 tersebut ? Atas masalah tersebut berbagai pendapat dari pakar ketatanegaraan mengemukakan sebagai berikut:

a. Logemann mengemukakan bahwa penjelasannya ditulis oleh Soepomo. ${ }^{16}$

b. Mas Soebagio mengemukakan bahwa Penjelasan Undang-undang Dasar 1945 mirip dengan pidato Soepomo. ${ }^{17}$

c. Joeniarto mengemukakan : "Semua pembicaraan-pembicaraan di dalam sidang-sidang BPUPKI dan pembicaraanpembicaraan PPKI, khususnya uraian dari Prof. Mr. Soepomo (Ketua Panitia Kecil Hukum Dasar pada waktu itu), ternyata

13. Ibid., halaman 51.

14. Ibid., halaman 52 s/d 58.

15. K.C. Wheare, "Modem Constitution", Oxford University Press, New York, 1975, halaman 34.

16. Simorangkir, op. cit., halaman 29.

17. Mas Soebagio, "Lembaran Negara RI Sebagai Tempat Pengundangan Dalam Kenyataan", Cetakan Ketiga, Alumni, Bandung, 1983, halaman 28. 
uraian-uraian dalam Penjelasan tersebut tiada suatu uraian pun yang bertentangan. ${ }^{18}$

d. J.C.T. Simorangkir mengemukakan bahwa Penjelasan Undang-undang Dasar 1945 disusun dan dibuat oleh Prof. Soepomo adalah benar dan tidak salah. ${ }^{19}$

Dari berbagai pendapat para ahli ketatanegaraan tersebut, penulis sependapat dan memperkuatnya. Sebab, penulis menemukan kenyataan bahwa dalam sidang BPUPKI tanggal 13 Juli 1945, Soepomo telah mengisyaratkan adanya Penjelasan dalam undang-undang dasar. Keinginan Soepomo ini dikemukakan ketika beliau menanggapi pertanyaan dari Wurjoningrat. ${ }^{20}$ Setelah Indonesia merdeka, Soepomo menjabat Menteri Kehakiman pada Kabinet Pertama RI ${ }^{21}$ yang ruang lingkup bidang tugasnya berkaitan pula dengan peraturan perundangundangan. Penjelasan Undang-undang Dasar 1945 ini kemudian dimuat dalam BRI No. 7 Tahun II 15 Pebruari 1946.

\section{Mencari dasar teoritis adanya Penjelasan Undang-undang Dasar 1945}

Untuk mencari dasar secara teoritis adanya Penjelasan Undang-undang Dasar 1945, penulis akan mengacu kepada pendapat Henc van Maarseven dan Ger van der Tang yang membedakan konstitusi dalam vague norm dan concrete norm. ${ }^{22}$ Vague norm adalah konstitusi yang berisi norma samar-samar, sedangkan concrete norm adalah konstitusi yang berisi norma kongkrit.

Dengan mengacu kepada pembedaan konstitusi dari Henc van Maarseven dan Ger van der Tang tersebut, maka Undang-undang Dasar 1945 termasuk tipe klasifikasi konstitusi yang "vague norm". Sebab, ditegaskan lebih jauh oleh kedua pakar di atas sebagai berikut:

"If a constitutions contains only vague norm, this allows a certain freedom for elaboration, suplemen-tation and interpretation (konstitusi yang berisi norma yang samasamar, akan memberikan kebebasan dalam penjabarannya, penambahan dan penafsirannya). ${ }^{23}$

Dari pendapat Henc van Maarseven dan Ger van der Tang tersebut, jelas bahwa adanya penjelasan Undang-undang Dasar 1945 adalah merupakan konsekuensi dari Undang-undang Dasar 1945 yang termasuk dalam tipe konstitusi "vague norm".

Selanjutnya masalah Penjelasan Undangan-undang Dasar 1945 ini dilihat dari bentuk-bentuk penjelasan yang dikemukakan oleh Bagir Manan, ${ }^{24}$ adalah termasuk dalam penjelasan yang berada di luar batang tubuh peraturan perundang-undangan. Dengan kata lain Penjelasan Undangan-undang Dasar 1945 tidak merupakan satu kesatuan dengan Batang Tubuh Undang-undang Dasar $1945 .{ }^{25}$ Letak Penjelasan yang berada di luar Batang Tubuh Undang-undang Dasar 1945 ini berbeda dengan Konstitusi Philipina 1973. Sebab, dalam Konstitusi Philipina

18. Joeniarto, op. cit, halaman 19.

19. J. C. T. Simorangkir, op. cit., halaman 32.

20. Mohammad Yamin, op. cit., halaman 261.

21. Bibit Soeprapto, "Perkembangan Kabinet dan Pemerintahan di Indonesia", Cetakan Pertama, Ghalia Indonesia, Jakarta, 1985, halaman 17.

22. Henc van Maarseveen dan Ger van der Tang, "Written Constitutions A Computerized Comparative Study", Oceana Publications Inc., Dobb's Ferry, New York, 1978, halaman 255.

23. Ibid.

24. Bagir Manan, op. cit., halaman 330.

25. Ibid., halaman 332. 
terdapat adanya "Explanations" setelah rumusan pasal-pasalriya. ${ }^{26}$

Meskipun.demikian adanya Penjelasan yang berada di luar Batang Tubuh Undangundang Dasar 1945 ini telah diterima sebagai "Penjelasan Otentik" oleh ketetapan MPRS No. XX Tahun 1966 yang hingga sekarang masih dinyatakan berlaku. Adanya Penjelasan yang merupakan upaya "Penafsiran Resmi" karena penjelasan termasuk salah satu metode penafsiran akan berguna dalam memahami jiwa dan makna Pembukaan dan Batang Tubuh Undangundang Dasar 1945.

\section{Hubungan Antara Materi Muatan Penjelasan Dengan Materi Muatan Batang Tubuh Undang-undang Dasar 1945 (Studi Tentang Sistem Pemerintahan Negara)}

Pengaturan sistem pemerintahan dalam Batang Tubuh Undang-undang Dasar 1945 tersebar dalam pasal-pasal : Pasal 1 Ayat (2), Pasal 2 Ayat (1), Pasal 3, Pasal 6 ayat (1), Pasal 19 Ayat (1), Pasal 20 Ayat (1) dan (2). dan Pasal 21 Ayat (1) dan (2). Pasal-pasal tersebut adalah yang bertalian dengan lembaga perwakilan.

Sedangkan pengaturan sistem pemerintahan dalam Batang Tubuh Undangundang Dasar 1945 yang bertalian dengan eksekutif adalah : Pasal 4 Ayat (1) dan (2), Pasal 5 Ayat (1) dan (2), Pasal 7, Pasal 8. Pasal 9, Pasal 10, Pasal 11, Pasal 12, Pasal 13 Ayat (1) dan (2), Pasal 14, Pasal 15, Pasal 17 Ayat (1), (2) dan (3), Pasal 22 Ayat (1), (2), dan (3), dan Pasal 23 Ayat (1).

Bertalian dengan sistem pemerintahan ini, S.L. Witman dan J.J. Wuest dalam Visual
Outline of Comparative Goverment ${ }^{27}$ mengemukakan adanya ciri-ciri sistem pemerintahan parlementer dan presidensiil sebagai berikut:

1. Sistem Pemerintahan Parlementer :

a. didasarkan pada prinsip pembagian kekuasaan :

b. terdapat adanya tanggung jawab secara timbal balik antara eksekutif dan legislatif; karena itu eksekutif dapat membubarkan legislatif atau eksekutif harus meletakkan jabatan bersamasama dengan meng-istirahatkan kabinet ketika kebijaksanaannya tidak dapat diterima oleh sebagian besar anggota legislatif.

c. terdapat pertanggung jawaban timbal balik antara eksekutif dan kabinet;

d. eksekutif (Perdana Menteri atau Kanselir) dipilih oleh Kepala Negara (Raja atau Presiden) berdasarkan pada dukungan mayoritas anggota parlemen.

2. Sistem Pemerintahan Presidensiil :

a. didasarkan pada prinsip pemisahan kekuasaan;

b. eksekutif tidak mempunyai kekuasaan untuk membubarkan legislatif maupun tidak ada keharusan untuk berhenti ketika kehilangan dukungan dari mayoritas anggota legislatif;

c. tidak ada pertanggung jawaban secara timbal balik antara Presiden dan Kabinetnya; pertanggung jawaban terakhir secara keseluruhan ada pada Presiden;

d. eksekutif dipilih oleh dewan pemilih.

Sementara itu Douglas V. Verny ${ }^{28}$ dalam melihat perbandingan antara sistem

26. Sri Soemantri, "Sistem-sistem ...", loc. cit.

27. S. L. Witman dan J.J. Wuest, "Visual Outline of Comparative Goverment". Littlefield. Adams \& Co, new Jersey, 1960; halaman $7 \mathrm{~s} / d 8$.

28. Douglas V. Vermy dan Aren Lijphart "Parliamentary Versus Presidential Goverment", Oxford University Press, New York, 1992, halaman 2 s/d 4. 
pemerintahan parlementer dan sistem pemerintahan presidensiil mengemukakan sebagai berikut:

1. Dalam pemerintahan parlementer Kepala Pemerintahan (Perdana Menteri, Kanselir dan sebagainya) dan Kabinetnya tergantung pada dukungan dari legislatif dan dapat dibubarkan oleh legislatif melalui cara pemungutan suara; sementara dalam bentuk pemerintahan presidensiil Kepala Pemerintahan selalu dinamakan Presiden yang dipilih untuk waktu yang pasti (tertentu) yang dalam keadaan normal tidak dapat dipaksa untuk berhenti oleh legislatif (kecuali dimungkinkan pergantian Presiden yang jarang terjadi melalui empeachment);

2. Presiden selaku Kepala Pemerintahan dipilih secara populer oleh pemilih baik secara langsung maupun oleh dewan pemilih, sedangkan Perdana Menteri oleh legislatif;

3. Sistem parlementer mempunyai suatu kelompok (kollegia) dalam eksekutif, sementara sistem presidensiil hanya mempunyai satu orang, tidak merupakan suatu kelompok eksekutif;

4. Presiden adalah Kepala Negara dan Kepala Pemerintahan, sementara Perdana Menteri hanyalah Kepala Pemerintahan;

5. Presiden tidak dapat menjadi eksekutif sekaligius legislatif, sementara Perdana Menteri dan anggota-anggotanya adalah anggota legislatif.

Apabila ketentuan pasal-pasal yang berkaitan dengan lembaga perwakilan dan lembaga eksekutif dalam Batang Tubuh Undang-undang Dasar 1945 yang telah diketengahkan di muka dikaji dari pendapat S.L. Witman dan J.J. Wuest serta Douglas
V. Verny tersebut, maka sistem pemerintahan dalam Batang Tubuh Undang-undang Dasar 1945 adalah cenderung dan lebih menonjol kepada sistem pemerintahan presidensiil. Meskipun demikian harus diakui tetap adanya unsur parlementer.

Sementara itu sistem pemerintahan dalam Penjelasan Undang-undang Dasar 1945 yang secara khusus dituangkan dalam suatu judul "sistem Pemerintahan Negara" yang memuat 7 (tujuh kunci pokok. sistem pemerintahan, apabila dikaji dari S. L. Witman dan-J.J. Wuest serta Douglas V. Verny di atas, akan terlihat bahwa ciri parlementernya diakui adanya, namun dominasi sistem pemerintahan presidensiil lebih tampak dan terasa dianut dalam Penjelasan Undangundang Dasar 1945.

Dengan melihat pada sistem pemerintahan dalam Batang Tubuh maupun dalam Penjelasan Undangan-undang Dasar 1945 tersebut, tampak sekilas adalah sama. Artinya antara keduanya dapat ditarik adanya benang merah yang memberikan penekanan pada dianutnya sistem pemerintahan presidensiil dan sama-sama mengakui adanya unsur sistem pemerintahan parlementer.

Apabila antara sistem pemerintahan tersebut dikaji secara lebih mendalam, akan terlihat bahwa unsur parlementernya dalam Penjelasan lebih tegas jika dibandingkan dalam Batang Tubuh Undang-undang Dasar 1945. Sebab, dalam Batang Tubuh tidak terlihat adanya pasal yang secara langsung mengatur pertanggungjawaban Presiden, meskipun melalui berbagai penafsiran dapat ditarik dari ketentuan Pasal 6 Ayat (2) dan Pasal 9 Undang-undang Dasar 1945. ${ }^{29}$ Sementara itu masalah pertanggungjawaban Presiden kepada MPR terdapat ketentuan secara jelas dan tegas dalam Penjelasan

29. Soewoto, "Kekuasaan dan Tanggung jawab Presiden RI, Suatu Penelitian Segi-segi Teoritik dan Yuridik Pertanggungjawaban Kekuasaan", Disertasi Fak. Pasca sarjana Unair, Surabaya, 1990, halaman 183. 
Undangan-undang Dasar 1945.

Dengan melihat pada urian di atas, maka hubungan yang dapat dikemukakan antara sistem pemerintahan dalam Penjelasan dengan sistem pemerintahan dalam Batang Tubuh Undang-undang Dasar 1945 adalah sebagai berikut: sistem pemerintahan dalam Penjelasan merupakan upaya "penafsiran resmi" terhadap sistem pemerintahan dalam Batang Tubuh Undang-undang Dasar 1945. Akan tetapi penafsiran resmi tersebut, meskipun memberikan tekanan sama dalam masalah dianutnya sistem presidensiil, namun ternyata ada sedikit perbedaan dalam masalah diakuinya sistem parlementer.

Selanjutnya perlu dikemukakan bahwa meskipun terdapat sedikit perbedaan antara sistem pemerintahan dalam Penjelasan dengan sistem pemerintahan dalam Batang Tubuh Undang-undang Dasar 1945, namun adanya pertanggungjawaban Presiden kepada MPR dalam Penjelasan lebih memberikan arti positif dalam rangka responsible goverment dalam sistem pemerintahan di Indonesia. Oleh karena itu, meskipun secara teoritis penjelasan tidak boleh bertentangan dengan batang tubuhnya, namun dalam masalah sistem pemerintahan dalam Penjelasan Undangan-undang Dasar 1945 ini tidak perlu dilakukan perubahan. Justru akan lebih baik jika dalam Batang Tubuh Undang-undang Dasar 1945 terdapat suatu pasal yang secara jelas dan tegas mengatur tentang pertanggungjawaban Presiden kepada MPR. Meskipun demikian, jika ukuran pertanggung jawaban Presiden kepada MPR yang terdapat dalam Penjelasan Undang-undang Dasar 1945 dikaji lebih mendalam, maka akan terlihat bahwa ukuran pertanggungjawaban tersebut bersifat sangat umum. Sebab, Presiden baru dapat diminta pertanggungjawabanhya dalam masa jabatan yang dipegangnya, apabila Presiden telah dengan sungguhsungguh melanggar haluan negara yang ditetapkan dalam Undang-undang Dasar 1945 maupun oleh MPR.

Dari uraian di atas, tampak semakin jelas bahwa sistem pemerintahan menurut Undang-undang Dasar 1945 lebih dominan sistem pemerintahan presidensiilnya. Sebab. Presiden akan tetap memangku masa jabatannya selama lima tahun yang telah ditentukan. Artinya dalam keadaan normal, tidak akan terjadi Presiden diminta pertanggungjawabannya oleh MPR bertalian dengan pelaksanaan tugas dan kekuasaannya.

Akhirnya dapat diketemukan bahwa bertalian dengan sistem pemerintahan menurut Undang-undang Dasar 1945. pembentuk Undang-undang Dasar 1945 ingin menciptakan suatu sistem pemerintahan yang meletakkan posisi eksekutif yang kuat, namun tetap dikontrol dengan adanya pertanggungjawaban kepada MPR meskipun ukurannya sangat umum.

\section{Penutup}

Adanya benang merah antara sistem pemerintahan dalam Penjelasan dan sistem pemerintahan dalam Batang Tubuh Undangundang Dasar 1945 ini menunjukkan bahwa Soepomo, dengan tidak mengurangi rasa hormat kepada anggota BPUPKI dan PPKI yang lainnya berperan besar dalam penyusunan dan penetapan Undang-undang Dasar 1945.

\section{DAFTAR PUSTAKA}

Bagir Manan, Hubungan Antara Pusat dan Daerah Menurut UUD 1945, Disertasi, Unpad, Bandung, 1990.

Bibit Soeprapto, Perkembangan Kabinet dan Pemerintahan di Indonesia, Cetakan Pertama, Ghalia Indonesia, Jakarta, 1985.

Joeniarto, Sejarah Ketatanegaraan RI, Cetakan Ketiga, Bina Aksara, Jakarta, 1986. 
Kahn, George Mc Turnan, Nasionalisme dan Revolusi di Indonesia, terjemahan Ismail bin Muhammad dan Zaharom bin Abdul Rashid, Cetakan Pertama, Dewan Bahasa dan Pustaka Kementerian Pelajaran Malaysia, Kuala Lumpur, 1980.

Lijphart, Arent, Parliamentary Versus Presidential Government, Oxford University Press, New York, 1992.

Marseveen, Henc van dan Ger van der Tang, Written Constituions A Computerized Comparative Study, Oceana Publications Inc., Dobbs Ferry, New York, 1978.

Mas Soebagio, Lembaran Negara RI Sebagai Tempat Pengundangan Dalam Kenyataan, Cetakan Ketiga, Alumni, Bandung, 1983. Moh. Hatta, Sekitar Proklamasi, Cetakan Kedua, Tintamas, Jakarta, 1970.

Mohammad Yamin, Naskah Persiapan UUD 1945, Jilid Pertama, 1971.

Moh. Tolchah Mansoer, Pembahasan Beberapa Aspek Kekuasaan-kekuasaan Eksekutif dan Legislatif di Indonesia, Disertasi, Cetakan Kedua, Pradnya Paramita, Jakarta, 1977.

Pringgodogdo, A.G., Perubahan Kabinet Presidensiil Menjadi Kabinet Parlementer, Yayasan Fonds Gajah
Mada, Yogyakarta, tanpa tahun.

Saafarudin Bahaar, Risalah Sidang BPUPKI dan PPKI, Cetakan Kedua, Edisi II, Sekretariat Negara, Jakarta, 1992.

Simorangkir, J.C.T., Penetapan UUD Dilihat Dari Segi IImu Hukum Tata Negara, Gunung Agung, Jakarta, 1984.

Soewoto, Kekuasaan dan Tanggung Jawab Presiden RI, Suatu Penelitian Segi-segi Teoritik dan Yuridik Pertanggungjawaban Kekuasaan, Disertasi, Unair, Surabaya, 1990.

Sri Soemantri, Prosedur dan Sistem Perubahan Konstitusi, Cetakan IV, Alumni, Bandung, 1987.

----, Tentang-lembaga Negara Menurut UUD 1945, Cetakan Kelima, Alumni Bandung, 1986.

, Sistem-sistem Pemerintahan Negaranegara Asean, Tarsito, Bandung, 1976.

Wheare, K.C. Modern Constitution, Oxford Univesity Press, New York, 1975.

Wirjono Prodjodikoro, Asas-asas Hukum Tata Negara di Indonesia, Cetakan Kelima, Dian Rakyat, Jakarta, 1983.

Witman, S.L. dan J.J. Wuest, Visual Outline of Comparative Government, Littlefield, Adams and Co. New Jersey, 1960.

Aturan Dasar dan Peraturan Perüundangundangan

Undang-undang Dasar 1945 dañ KetetapanKetetapan MPR

7 Saifuddin, SH, M Hum, adalah alumni FH-UII. Gelar Master diraih dan Universitas Padjajaran Bandung. Kini sebagai dosen FH UII serta sebagai Kabid Administrasi Keuangan Magister Hukum UII. 